\title{
Advances in marine phycology on the basis of cultivation
}

\author{
P. KORNMANN \\ Biologische Anstalt Helgoland (Meeresstation); Helgoland, Germany (FRG)
}

KURZFASSUNG: Fortschritte in der marinen Phykologie auf der Basis des Kulturexperiments. Die Kultur von Algen im Laboratorium ist zu einer unentbehrlichen Grundlage der modernen Algenforschung geworden. Entwicklungsgeschichtliche Untersuchungen dienen ebenso der Klärung vollständiger Lebenszyklen wie sie auch über Einzelheiten von Wachstums- und Teilungsvorgängen Aufschluß geben. Die Ergebnisse solcher Untersuchungen sind für die Taxonomie von Bedeutung, besonders bei morphologisch einfachen Arten, die zusätzlicher Unterscheidungsmerkmale bedürfen. Auf der Grundlage einer umfassenden Kenntnis der Arten lassen sich phylogenetische Zusammenhänge erkennen. Wie die Anwendung der Kulturmethode diese Gebiete der marinen Phykologie bereichert hat, wird an einer Reihe von Beispielen, meist aus der Arbeit des Verfassers, aufgezeigt.

\section{INTRODUCTION}

Cultivation of marine algae under laboratory conditions represents an indispensable fundament in all fields of modern phycology. Primarily used for the elucidation of complete lif e his tories, the method has proved useful for studies of $\mathrm{g} \mathrm{row} \mathrm{th}$ and cell division. Algal genera of simple morphological structure often lack definite structural characteristics for the distinction of species. Culture experiments may yield additional information, thus providing a basis for modern $\mathrm{tax}$ on $\mathrm{o}$ $\mathrm{mical} \mathrm{research}$. Finally, the knowledge obtained in cultivation experiments is likely to allow a better understanding of phylogenetic relationships. Examples documenting each of the statements made are presented in this paper; they are largely based upon the author's own work.

\section{LIFE HISTORIES}

The life history of Saccorbiza bulbosa - an epoch-making discovery

Cultivation of algae under laboratory conditions with the primary aim to elucidate life histories and ontogenetical developments has been employed as a research 
tool only since a few decades. The classical investigations by SaUvageaU (1915) on the heteromorphic life cycle of Saccorbiza bulbosa, soon confirmed for other genera of the Laminariaceae, opened up new vistas beyond the marine biological horizon of the early 20th Century. Since suitable nutritional media for cultivation of marine algae were already available in the nineteen twenties, many new surprising discoveries on algal biology followed the epoch-making discovery by SAUvageau. The present paper refers to some of the most interesting examples in this field of phycology.

During his studies on Helgoland, Schreiber (1930) was able to add important new information to our knowledge on the life cycles of Laminaria. Employing an ingenious method, he succeeded in breeding most, sometimes even all, 32 zoospores of a single sporangium. Half of them developed into male, the other half into female gametophytes, thus indicating genotypic sex-determination in Laminaria saccharina.

A diplohaplophasic cycle of isomorphic generations was demonstrated by HARTMANN (1929) and FöYN $(1929,1934 a, b)$ in the Chlorophycean genera Enteromorpha, Ulva, Cladophora and Chaetomorpha.

\section{Heteromorphic alternation in Derbesia marina}

Carefully and critically conducted cultivation experiments allow new insight into taxonomic relationships. For years, doubt has been cast on the statement that Derbesia marina and Halicystis ovalis - siphoneous green algae - are life history stages of one and the same alga. Admittedly, they are morphologically quite dissimilar. The unseptate slender filaments of Derbesia marina are branched, and they bear club-shaped sporangia which produce large zoospores with a subterminal collar of flagella. Halicystis ovalis, on the other hand, is an ovoid or globular bladder; its rhizoidal portion penetrates the calcareous crusts of Lithothamnion. Biflagellate gametes, known to occur commonly in green algae, are produced by male and female plants. Hollenserg (1935) suggested that Halicystis of the Californian coast, referred to $H$. ovalis, rises directly from the zygote. Raising zoospores of Derbesia marina, I obtained small flaments which changed into typical Halicystis ovalis bladders in the course of some months. The filamentous generation originated from the zygotes of these plants (KoRNMANN 1938). In view of the different findings of HOLLENBERG, the validity of my observations was questioned, until Feldmann (1950) confirmed the heteromorphic alternation of Derbesia tenuissima and Halicystis parvula of the French and Mediterranean coasts. Recently, HuSTEDE (1964) proved Derbesia neglecta to be the sporophyte of Bryopsis balymeniae, a new and unexpected variation of the prototype. On the basis of strains from Helgoland, NeumanN (1969) furnished proof that reduction division precedes zoospore formation in the lateral sporangia of Derbesia marina. Life history and nuclear phases of the alga are illustrated in the left part of Figure 1.

\section{Mutation in Derbesia marina}

For more than twelve years, the heteromorphic alternation of generations proved to be obligatory. Only once has a significant irregularity been established. Five years 
ago, a single Derbesia-plant was found in a dish amidst a large number of young Halicystis-stages (KoRNMANN 1966b). This plant was characterized by a morphological peculiarity: the filaments originated from a central globule. In other respects filaments and sporangia did not differ from those of typical Derbesia marina, but its zoospores developed directly into Derbesia, instead of producing a gametophytical generation.

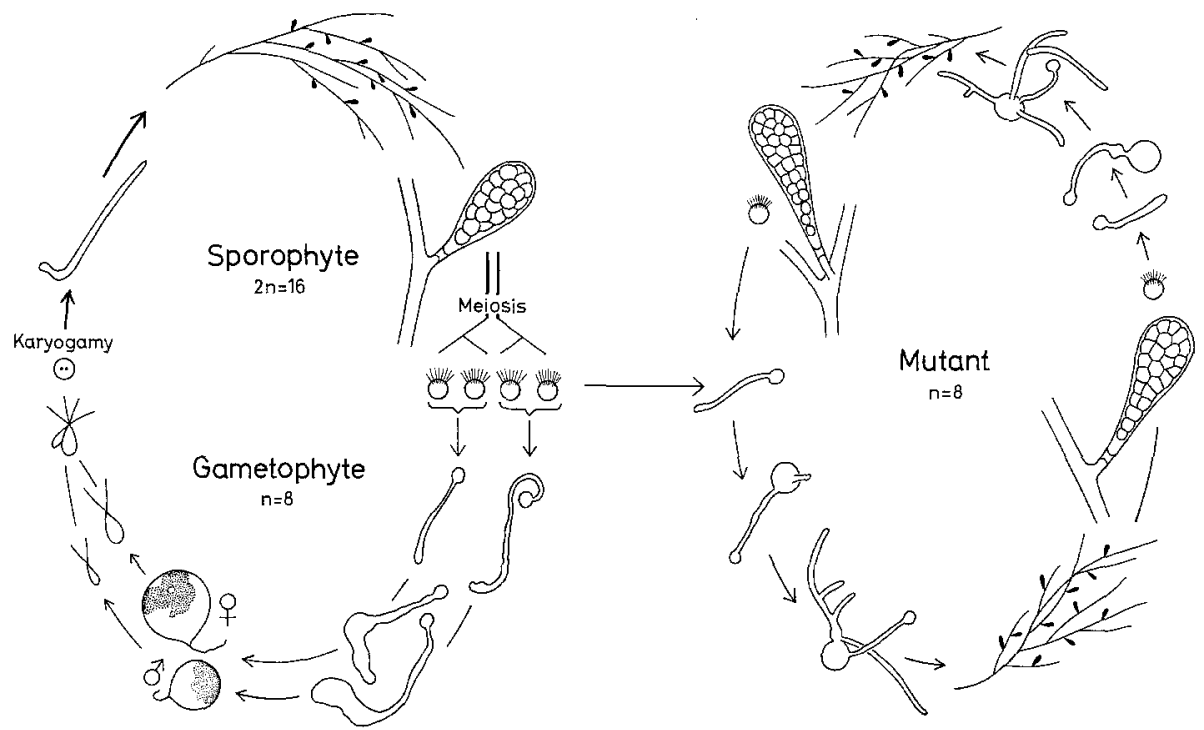

Fig. 1: Heteromorphic life cycle of Derbesia marina (at left). Alternation of isomorphic asexual generations in the mutated form (at right)

The end of the filamentous germination stage increased into a small vesicle. At an age of 4 to 5 weeks, filaments grew out of the globular thickening, thus renewing the characteristic attribute of the motherplant. Within two years 12 Derbesia generations succeeded one another, without any occurrence of the Halicystis stage (Fig. 1, right).

Quite accidentally we witnessed the genesis of a new algal species, arising from Derbesia marina by mutation. Its special character is the total lack of sexuality, the swarmers being completely neutral. Usually sporophytes are called asexual, an inappropriate term as this generation actually includes both sexes which become separated during zoospore formation.

The process that happened before our eyes must now be considered from a more general point of view. FELDMANN (1952) has suggested that each somatic phase of an algal life history may be isolated; thus giving rise to independent species. This assumption has proved true in Derbesia marina, though not in the sense of Feldmann by formation of apomeiotic zoospores, but by mutation. We know from cytological work by NeumanN (1969) that the chromosome number of the novelty is 8 and that no reduction division takes places in its zoosporangia. A process like this may not be confined to forms with a heteromorphic life cycle, though its detection will be the most obvious in this case. Many genera of green algae include species with alternating 
generations as well as asexual propagation; for instance Ulotbrix, Monostroma, Acrosiphonia, Enteromorpha or Chatomorpha. Genetical relationships of such species on the analogy of the pattern demonstrated may be taken into consideration.

\section{Life histories under ecological aspects}

We know, from observations in the field, that species often occur in seasonal rhythms. It is, therefore, of interest to modify environmental conditions such as temperature and light, in cultivation experiments. With regard to life histories, the influence of temperature is most striking as will be exemplified on the basis of experiments with Urospora wormskioldii. This handsome and conspicuous alga was abundant near Helgoland only for some years at the beginning of this decade during the period March to May. We do not know why it has not been found previously and why it has disappeared.

In Urospora wormskioldii, unbranched monosiphonous filaments, up to $15 \mathrm{~cm}$ in length, alternate with microscopic dwarf plants and a unicellular Codiolum stage, respectively. The inter-relations between these very different somatic phases are shown in Figure 2, which demonstrates the results of culture experiments (KoRNMANN 1961a).

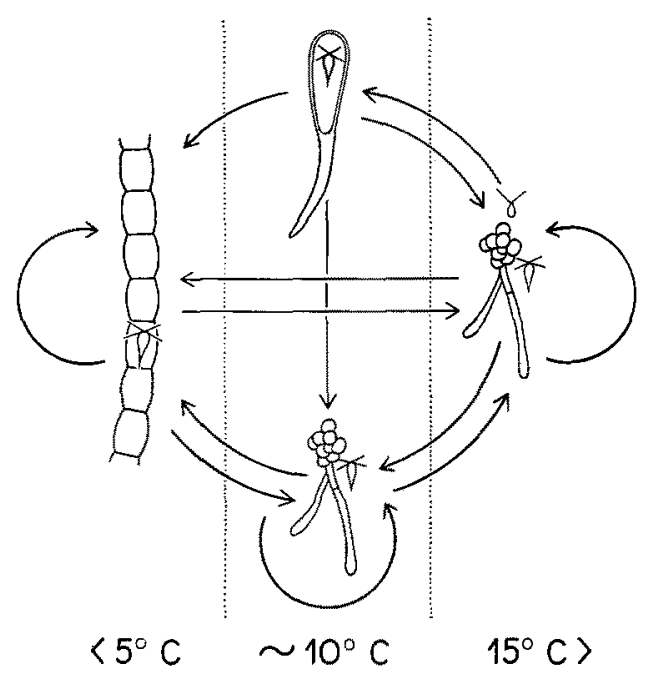

Fig. 2: Life history of Urospora wormskioldii in relation to temperature conditions. (After KORNMANN 1968)

The filamentous $U$. wormskioldii survives only at low temperatures near $5^{\circ} \mathrm{C}$. Its four-flagellated zoospores, which are elongated into a point at the posterior end, reproduce the mother plant at low temperature. They give rise to dwarf plants, however, in cultures at middle and higher temperatures $\left(10^{\circ}\right.$ or $\left.15^{\circ} \mathrm{C}\right)$. Dwarf plants also propagate abundantly by 4-ciliated zoospores, growing into dwarf plants again under 


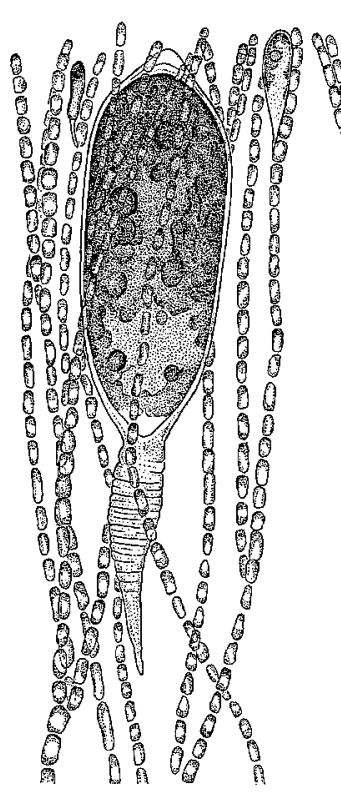

13.Juli 1964

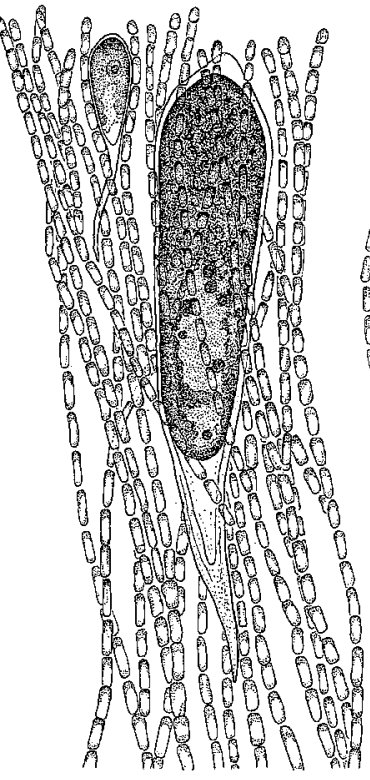

25. Aug. 1964

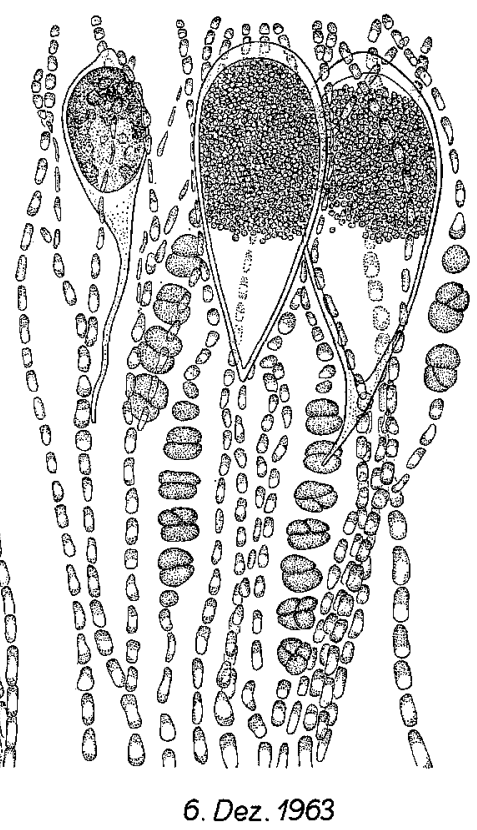

6. Dez. 1963

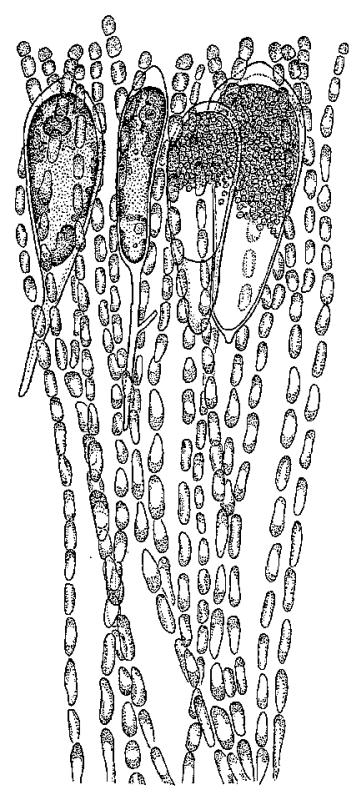

12. Febr. 1964

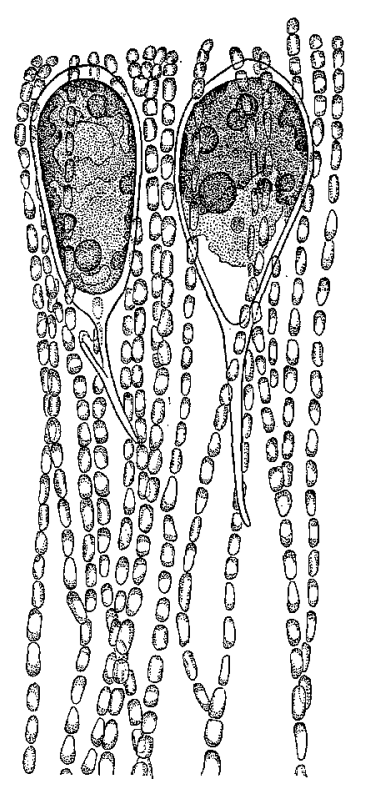

7. April 1964

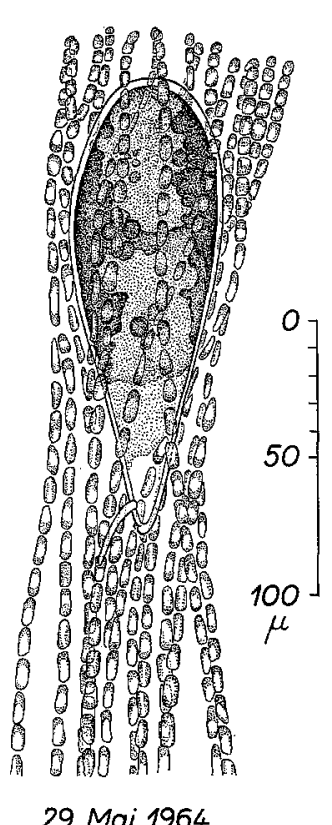

29. Mai 1964

Fig. 3: Spongomorpha aeruginosa. Seasonal rhythm of its sporophyte Codiolum petrocelidis in the natural host plant, Petrocelis bennedyi. (After Kornmann 1964) 
the same conditions. However, the same zoospores develop into filamentous plants at $5^{\circ} \mathrm{C}$. Additional biflagellate zoospores are produced only in the higher range of temperature; they lack sexuality and grow into small unicellular stalked plantlets. These were first described from Helgoland 115 years ago under the name of Codiolum. At $15^{\circ} \mathrm{C}$ the Codiolum stage does not become fertile, zoospores with 4 flagellae are produced only at middle or low temperatures respectively. According to the conditions of the culture experiment, the zoospores of Codiolum develop into Urospora-filaments or dwarf plants, respectively. These results permit interpretation of aspects of the seasonal rhythm of Urospora wormskioldii, i. e., the presence of filaments in March to May, and of fertile Codiolum in late autumn and winter.

Some more Codiolum "species" have been described. As far as hitherto investigated, they turned out to be life history stages of some genera of green algae, for instance Acrosiphonia or Spongomorpha. Codiolum petrocelidis is illustrated in Figure 3, growing within the frond of the red alga Petrocelis bennedyi. The youngest stages are found in July; they pass the following winter in a vegetative state and become fertile during the subsequent December to February. The gametophyte, Spongomorpba aeruginosa, occurs in spring. While, generally, only one cycle of generations is completed annually in the field, the succession of 3 to 4 cycles may be realized under the conditions of the culture-experiment (KORNMANN 1964).

\section{Concbocelis - a phase in the life cycle of Porphyra}

The life history of the red alga Porpbyra was elucidated by Drew $(1949,1954)$; a discovery not only of considerable scientific interest but also of extreme practical and economical consequences. Carpospores of female Porphyra develop into a shell inhabiting phase. As shown in Figure 4, growth of the filaments proceeds rather quickly. The shells become pink by the dense network of filaments within a short period of time.

A surprising synthesis leads to another genus of red algae. As early as 1892 Conchocelis rosea, an endophytical red alga forming pink patches on the inner surface of empty shells of molluscs, was described. Its systematical position remained obscure until Drew (1949) published her findings. Conchocelis represents a phase in the life history of Porphyra; its so-called conchospores give rise to the frond of Porphyra.

In culture, the Conchocelis phase is not obligately endophytical, but grows also free in the dishes. Figure 5 shows, on its left side, a fertile filament; four hours later most of its conchospores have been released. In the lower part of Figure 5 the mass of conchospores can be seen; it was produced by a small tuft of Conchocelis in a culture dish that was not moved; close by, young Porphyra-fronds from conchospores are visible (KORNMANN 1961b).

The discovery by Drew soon attained great practical importance. In Japan, Porphyra is used in large quantities as food for man. Its cultivation began some 300 years ago. The former methods of such "Nori-farming" were confined to afford a lodgement for the floating spores of Porphyra, by sinking lines of bamboo or brush into the muddy bottom. Modern farming methods begin in the laboratory, where 
Conchocelis is cultivated in mussel shells within large vessels. Bags containing mature Conchocelis are suspended in natural farming grounds between nylon nets, which are offered to the spores to settle on.

The area used for algal farming amounts to 85,000 acres; more than 150,000 fishermen are engaged in this occupation. The average total revenue attains as much as U.S. $\$ 110,000,000$ - per year. This information was published by Suto (1966).
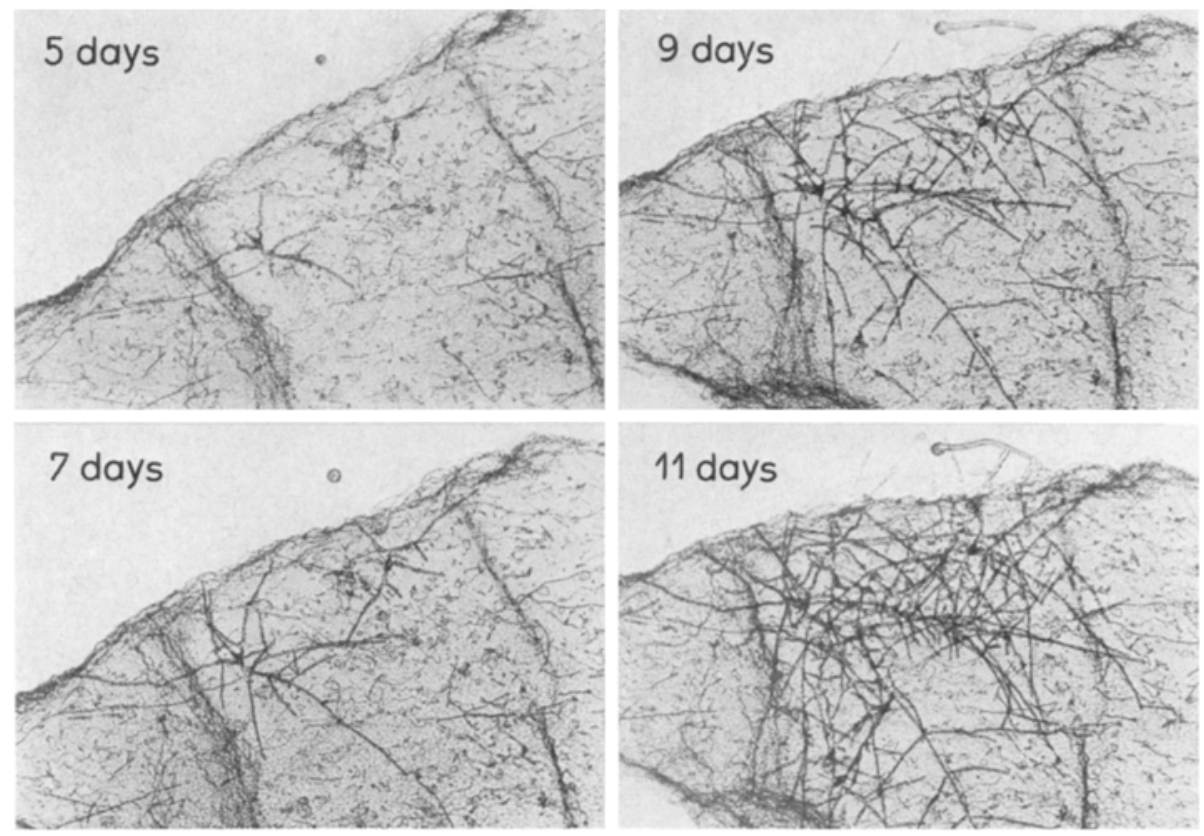

Fig. 4: Porphyra linearis. Growth of Conchocelis phase within a piece of mussel shell

\section{DEVELOPMENTAL PHYSIOLOGY}

\section{Apical growth in Acrosiphonia arcta}

Just as we are able to observe the whole life history in long term cultivation experiments, we may study processes of growth and cell-division. These basic functional events in the development of an organism are responsible for its specific structure. They are influenced by various environmental factors. Acrosiphonia, a monosiphonous branched green alga, for example, looks similar in shape to Cladophora. In February, its cells are much more elongated than in June, accordingly the ramification is more or less dense (Fig. 6). We may describe this species on the basis of its momentary morphological expression, but its total morphological potential becomes known only by analysing its development. For this purpose, observations under controlled laboratory conditions are necessary. In Acrosiphonia only the apical cell of an axis is 
capable of increasing in length. Figure 7 illustrates the development of the branched system of Acrosiphonia arcta, starting from an isolated apical cell. Growth is not impaired by this operation. 22 hrs after the beginning of the experiment, the filament consists of three cells, which result from apical cell division and regeneration of the
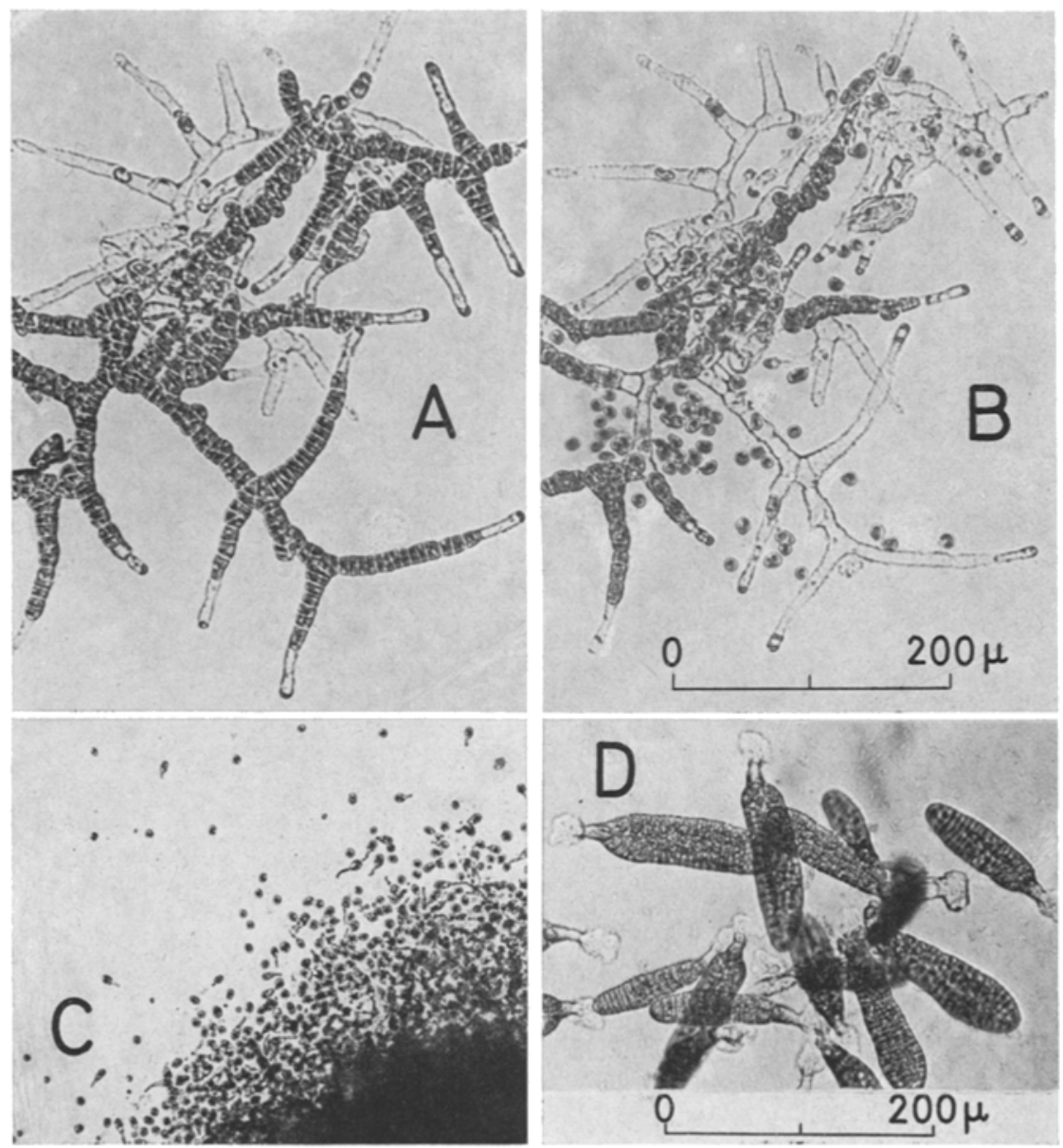

Fig. 5: Porphyra leucosticta, Conchocelis phase and sporelings of the monostromatic thallus. (Modified after KorNmanN 1961b. For further explanation compare the text)

one cut off which produces a rhizoidal cell. During the subsequent night, the elongated apical cell proceeds to divide again. The subapical cell, however, has not increased its length but has undergone an unequal division; the upper cell is shorter. A branch originates from its superior end. This pattern of growth is continuously repeated; the main axis and the branches produce a new apical cell every day. The daily increase is of equal size, but the rate of elongation is not the same for the individual axes. The diagram of summated apical growth thus represents a straight line. Varia- 
tion of the culture conditions (temperature, light intensity, rhythm of illumination versus darkness periods) brings about specific changes in the growth rate and habit of the object under consideration. At $15^{\circ} \mathrm{C}$ and under conditions of high light intensity, the tufts become dense and short-celled - in contrast to the shape resulting at $5^{0} \mathrm{C}$ and normal illumination. Similar variations also occur under natural conditions. Here, a broad field opens up for studies on developmental physiology.

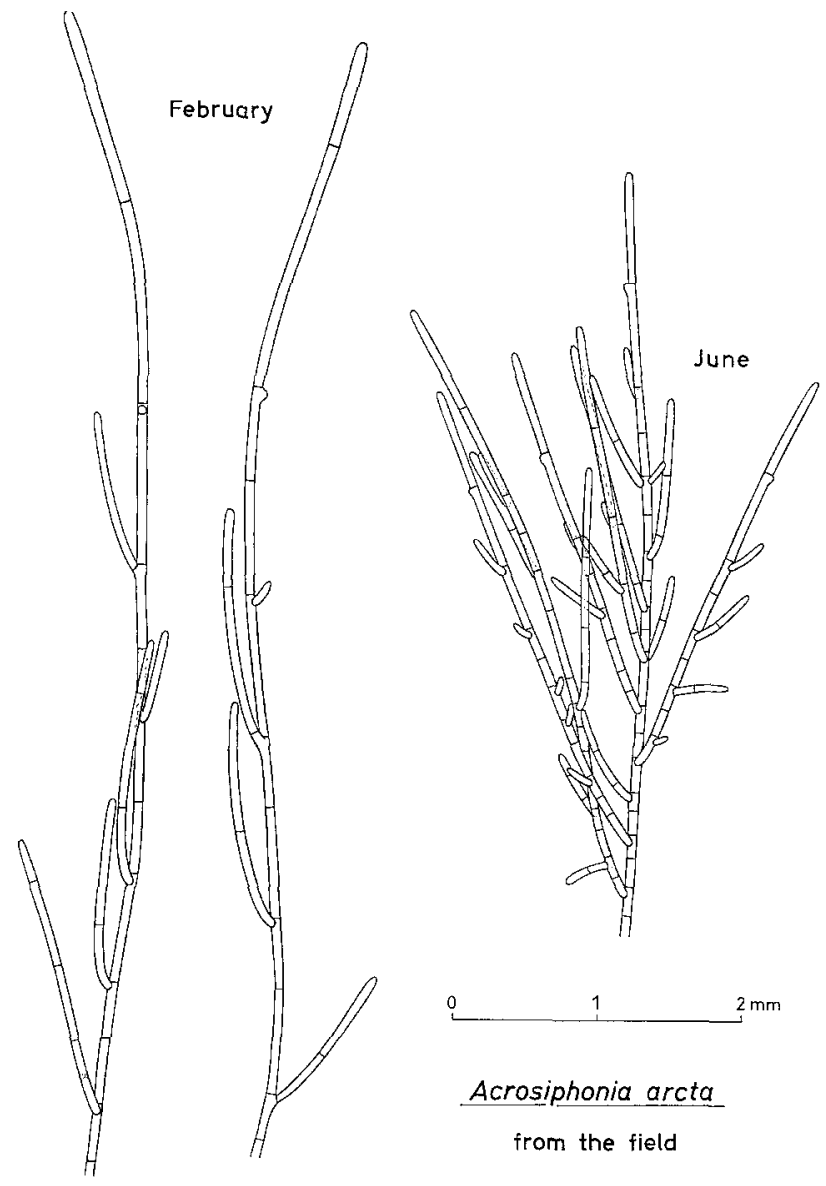

Fig. 6: Acrosiphonia arcta. Seasonal variations of shape. (Modified after Kornmann 1965b)

Under suitable culture conditions the apical cells divide synchronously, once a day, shortly after midnight. Details of this process are demonstrated in Figure 8. At eight o'clock in the evening, a hyaline ring differentiates in the dark-coloured protoplast of the tip region. This girdle becomes more and more distinct during the following hours, it appears to move towards the base. However, this is, in reality, not the case (it is an impression caused by the continuous lengthening of the apical zone). One waits for the division to take place at this clearly distinguished cell zone, that is, for 
the formation of a centripetal cross-wall section. However, one waits in vain. At one o'clock or half-past one, a very fine cross-wall can be observed (arrows). At this time, however, the hyaline ring is located considerably above the new cross-wall; but now it is really moving into an apical direction, diminishing in distinctness and finally

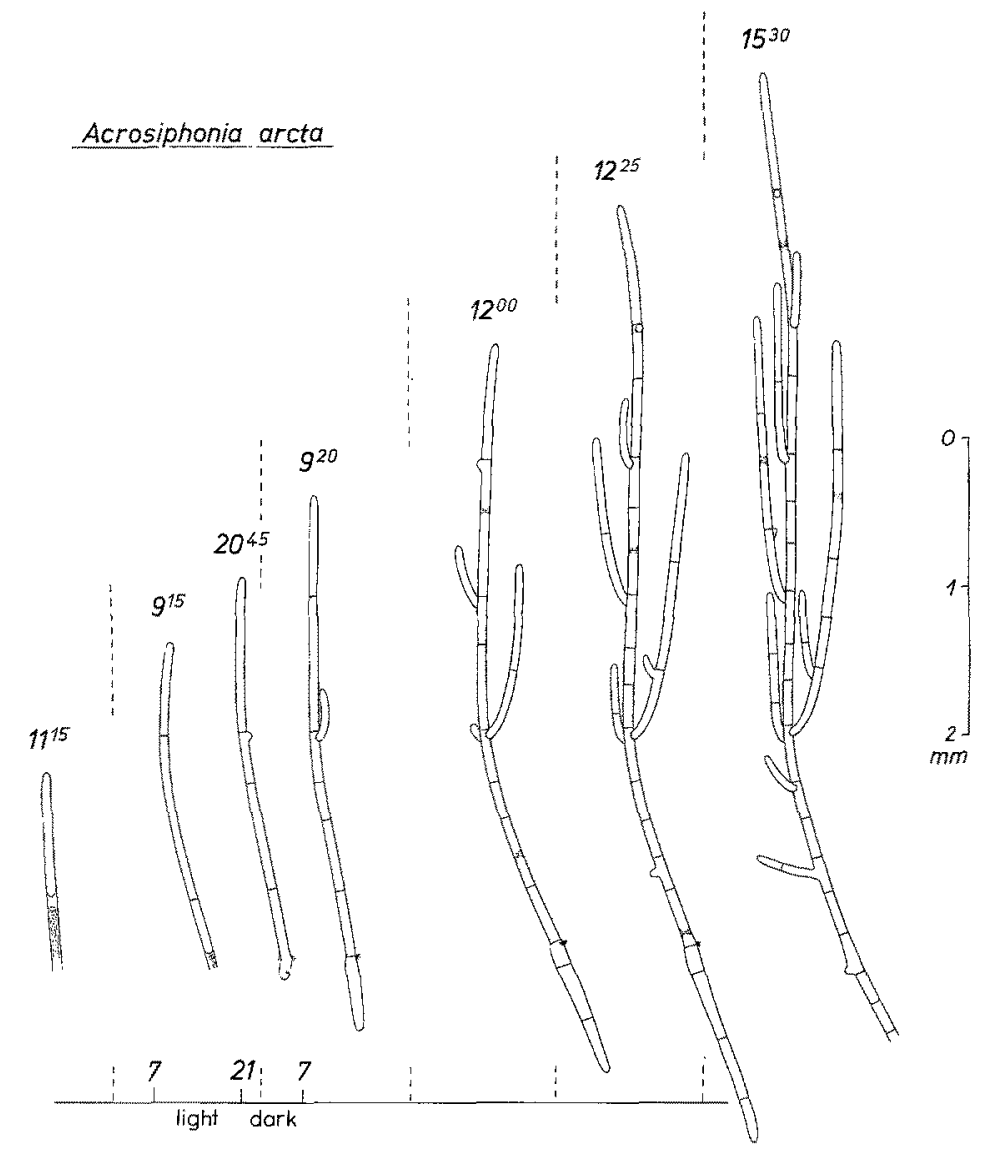

Fig. 7: Acrosipbonia arcta. Regeneration of the branched thallus from an isolated apical cell within five days. (Modified after KoRNMANN 1965a. For further explanation compare the text)

disappearing. In addition, at an equal distance from the cross-wall, a weakly visible ring moves downwards. At two o'clock, all new apical cells have become clearly separated and the protoplast has concentrated near the tip. It is amazing how fast the cell increases in length; in the subsequent evening it has attained three times its original length and proceeds to divide again.

Cytological attributes of cell division have been documented by staining (Fig. 9). As early as eight o'clock in the evening the tip region of the cell is free of nuclei, they have concentrated within the zone of the hyaline ring. Shortly after midnight, all nuclei divide simultaneously. Then they are distributed to the sister cells, whereby 

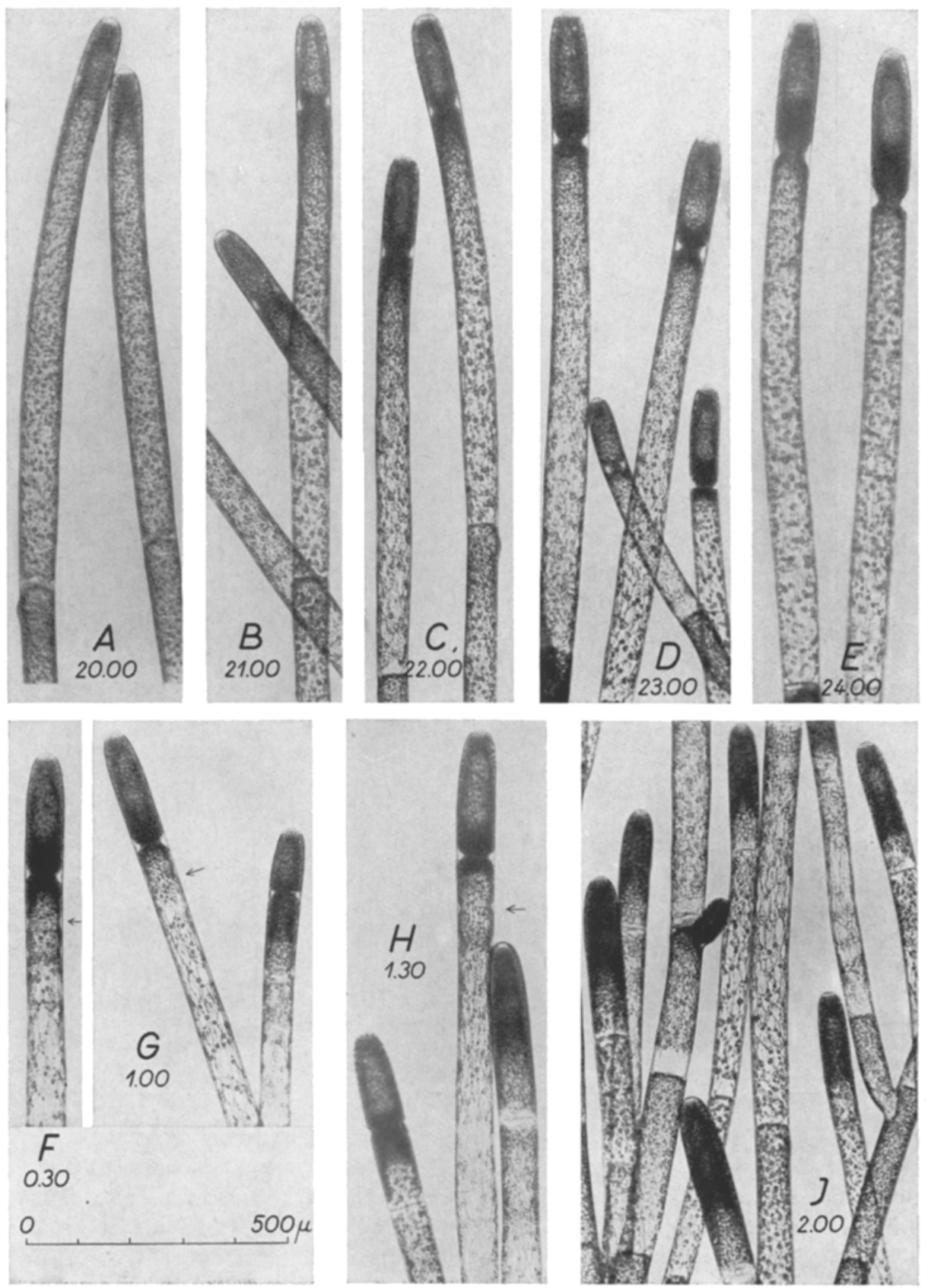

Fig. 8: Acrosiphonia arcta. Synchronous division of apical cells. (After Kornmann 1965a. For further explanation compare the text) 
the apical cell receives far more nuclei than the subapical one. This unequal division seems to be related to the specific function of the resulting cells. Size and growth rate of the apical cell are a function of its number of nuclei (KORNMANN 1965a).

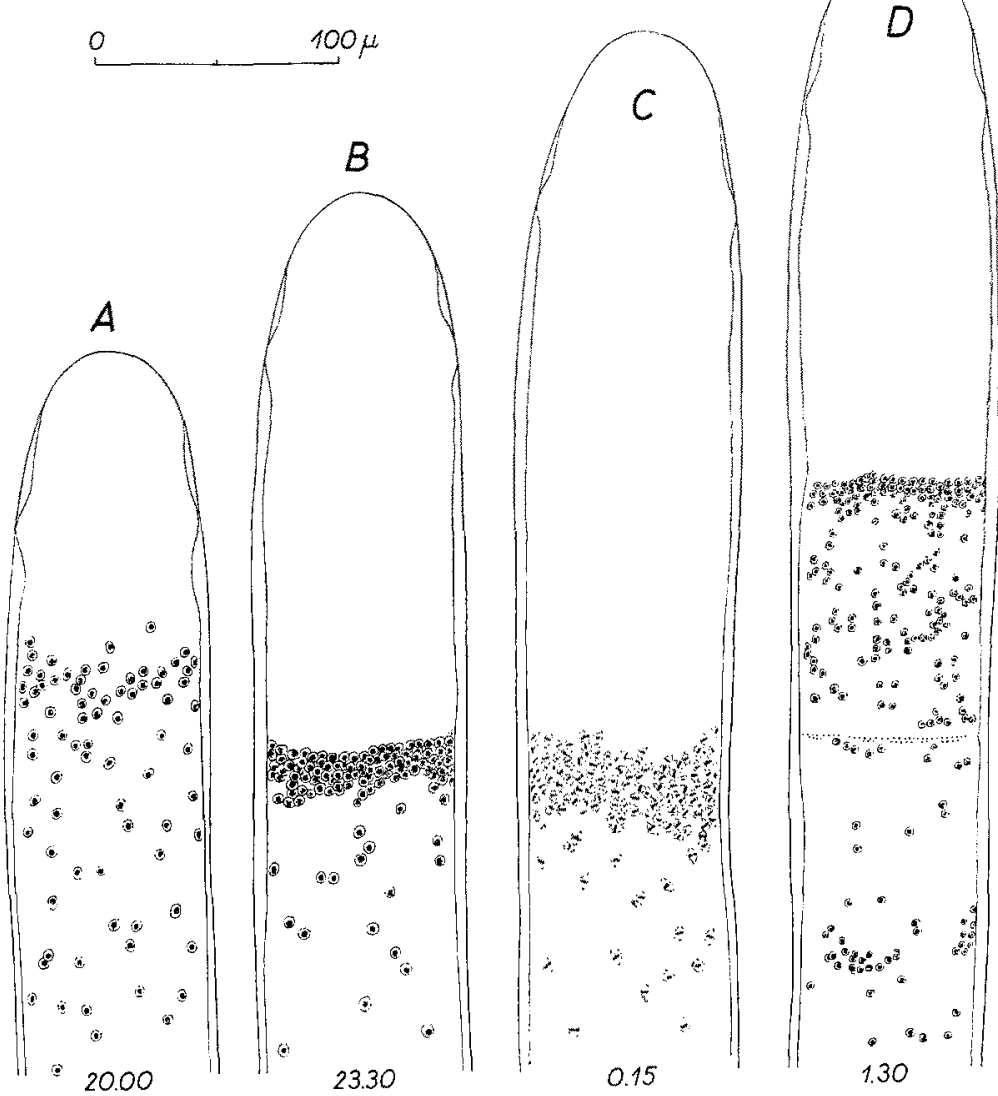

Fig. 9: Acrosiphonia arcta. Behaviour of nuclei in the apical cell during division. (After KORNMANN 1965a)

\section{Intercalary growth in Urospora wormskioldii}

Detailed observations on growth, as shown in the above-mentioned example, break new ground in the biology of algae. Acrosiphonia represents the type of apical growth which is necessarily combined with an unequal division of the apical cell. It is otherwise in intercalary growth, where all cells of a filament increase in length and divide. This growth type is clearly exemplified in unbranched monosiphonous green algae genera such as Urospora or Chaetomorpha. In Figure 10 the history of a single Urospora cell during its individual existence is shown, beginning and ending with a cell 
division. During the five days under consideration, the cell increases both in length and width. The outlines of the fragment are drawn in true proportions, whereas the number of nuclei is reduced in order to elucidate the principle of their behaviour.

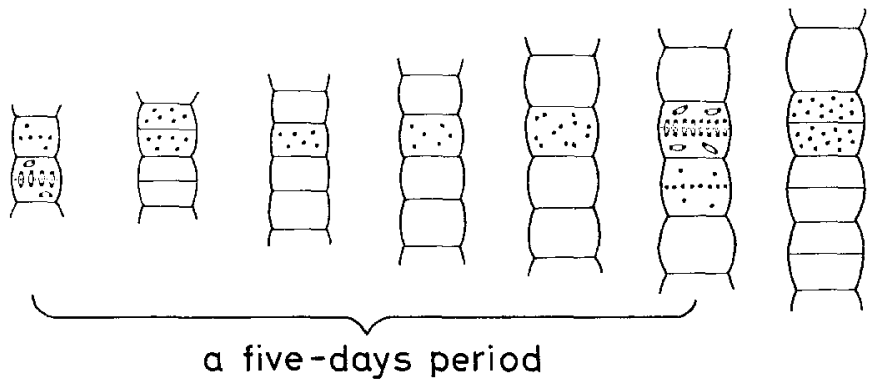

Fig. 10: Urospora wormskioldii. Scheme of intercalary growth, the number of nuclei reduced in order to point out the principle of their behaviour
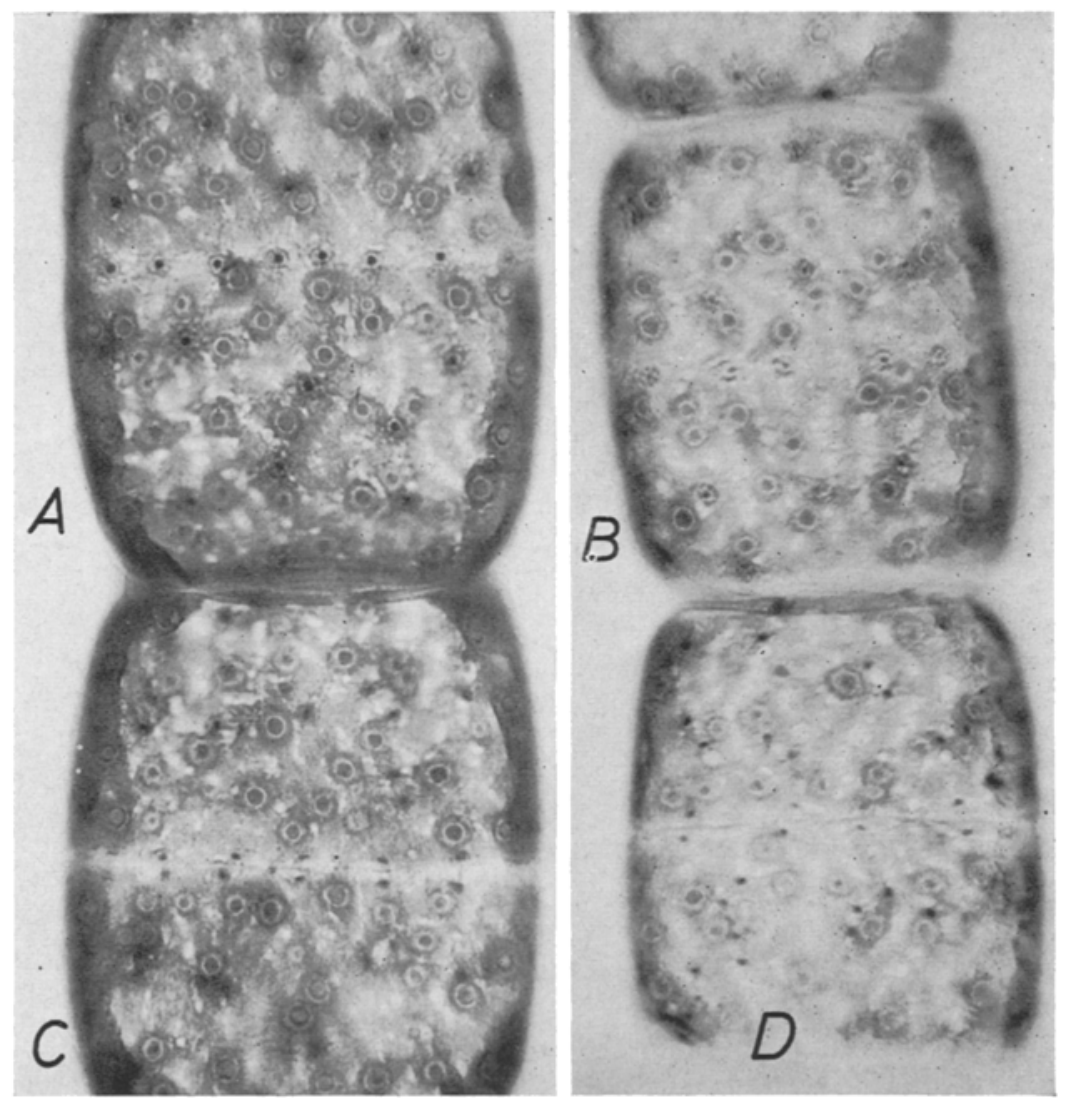

Fig. 11: Urospora wormskioldii. Cell division, combined with simultaneous mitoses. $A$ Part of the nuclei are arranged in an equatorial zone. $B$ Prophase. $C, D$ The new cross-wall is visible between pairs of nuclei. (400X; after Kornmann 1966a) 
A forthcoming cell division is announced by the appearance of a light hyaline equatorial zone in full-sized cells. Cell division is combined with mitosis, as proved by staining; some of the numerous nuclei are arranged in an equatorial girdle, whereas the remaining ones are distributed irregularly over the protoplast. Mitosis takes place simultaneously in all nuclei. It is obvious that the number of nuclei in the sister cells is not increased by this process. As the volume of the cell increases continuosly, the number of nuclei must be enlarged too. Duplication is effected by simultaneous mitoses of all nuclei not associated with cell division. This process occurs about one day previous to cell division, as deduced from the size of cells. In Figures 11 and 12 these processes are represented on the basis of stained material (KoRNMANN 1966a).

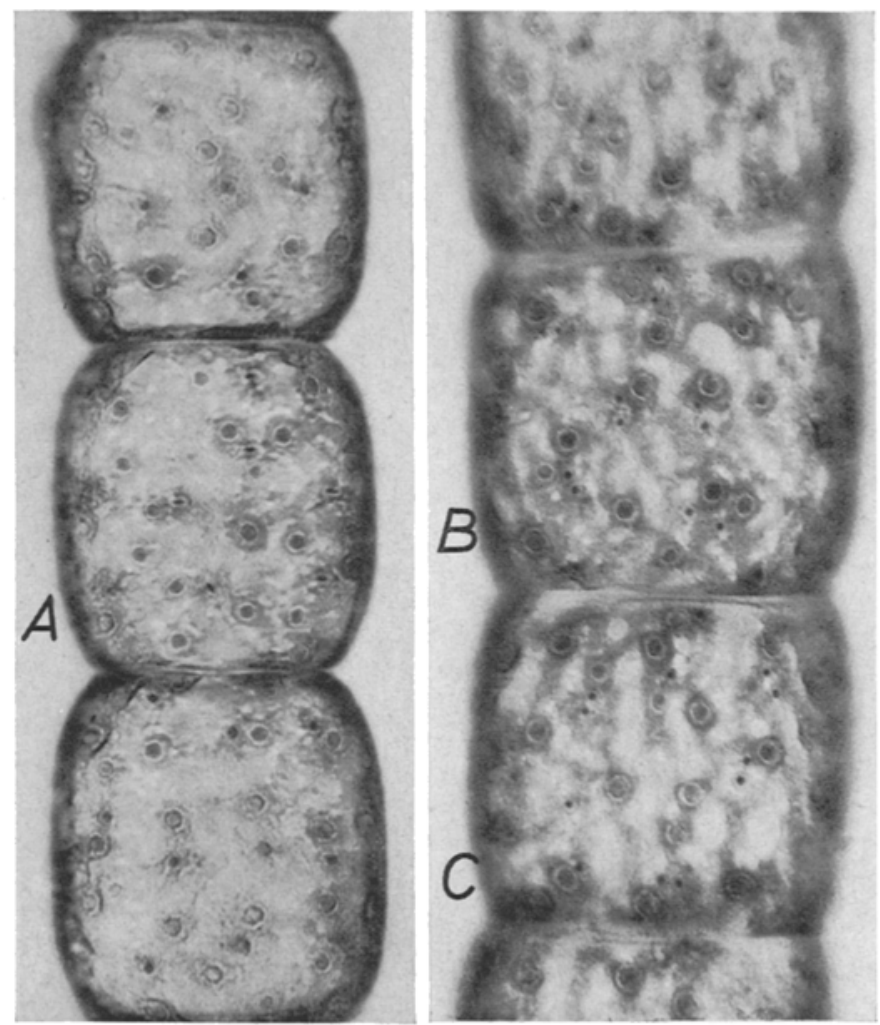

Fig. 12: Urospora wormskioldii. Simultaneous duplication of nuclei without cell division. $A$ Metaphase. $B, C$ Pairs of nuclei after mitoses. (400X; after Kornmann 1966a)

\section{Growth studies in Chaetomorphadarwinii}

Most interesting and instructive objects for the study of growth processes in marine algae are found in the chlorophycean genus Chaetomorpha, which is characterized by monosiphonous unbranched filaments. Chaetomorpha darwinii, an Austra- 
lian species, is most conspicuous by its large cells, attaining even in culture up to $1 \mathrm{~cm}$ in length. Filaments of the alga resemble strings of large and glistening green pearls. By the use of culture techniques it is no longer difficult to study living algae far away from their habitats. I am indebted to Mrs. S. C. Ducker of Melbourne

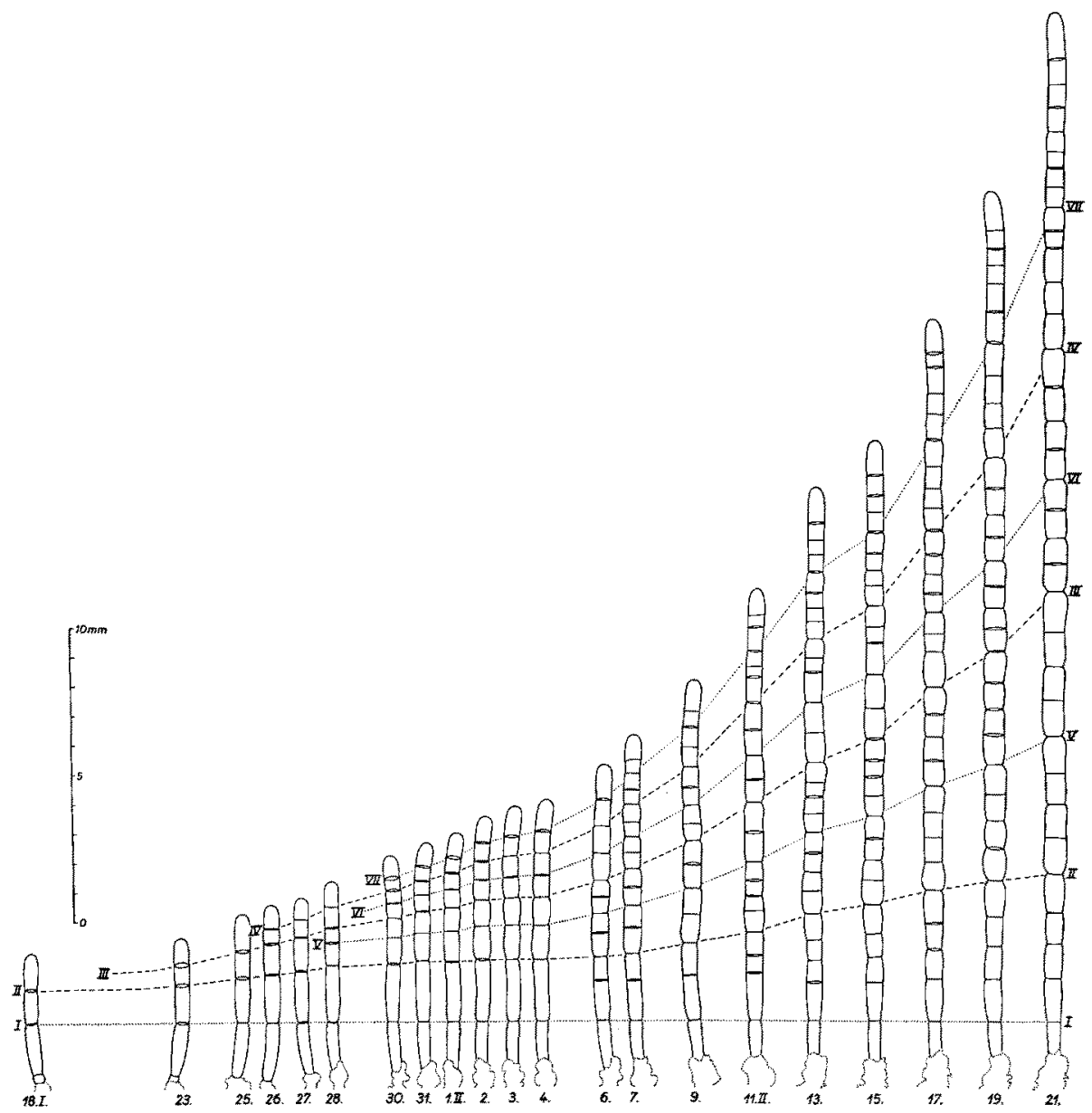

Fig. 13: Chaetomorpha darwinii. Intercalary growth of a young filament. Numbers I-VII indicate the sequence of cross-wall formation. (After KORNMANN 1969)

(Australia) for providing the material. Samples of Rbipioliopsis peltata and Callipsyma wilsonii arrived within three days in good condition. It was not possible, however, to cultivate these two algae as originally intended, because they were soon overgrown by numerous epiphytes which developed from germinating stages. In this way some 30 different species of green, brown and red algae could be isolated and grown in culture; among them were some 20 sporelings of Chaetomorpha darwinii. The whole life cycle of $C$, darwinit could be studied in culture; there is an alter- 


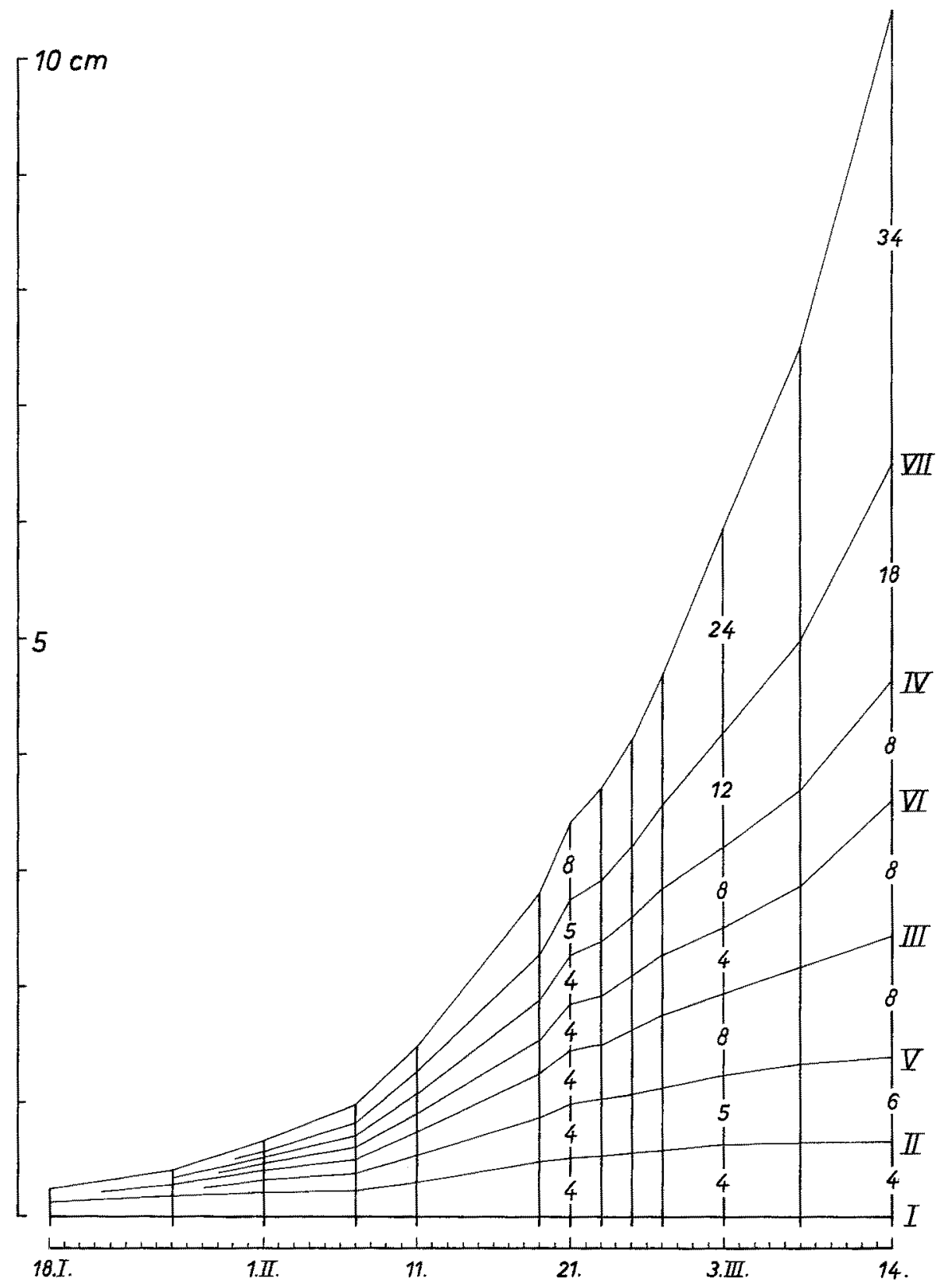

Fig. 14: Chaetomorpha darwinii. Growth of a filament within a two-months registration, following up Figure 13. The ciphers refer to the number of cells in the individual segments of the filament. (After Kornmann 1969) 
nation of isomorphic generations. Exact measurements of growth of a single filament were made in a long-term experiment by photos taken at intervals of a few days. Typical intercalary growth is demonstrated in Figure 13, the rate of cell division increases from the base to the top of the filament. The series is continued in the diagrammatic Figure 14; growth rates of the filament are exponential.

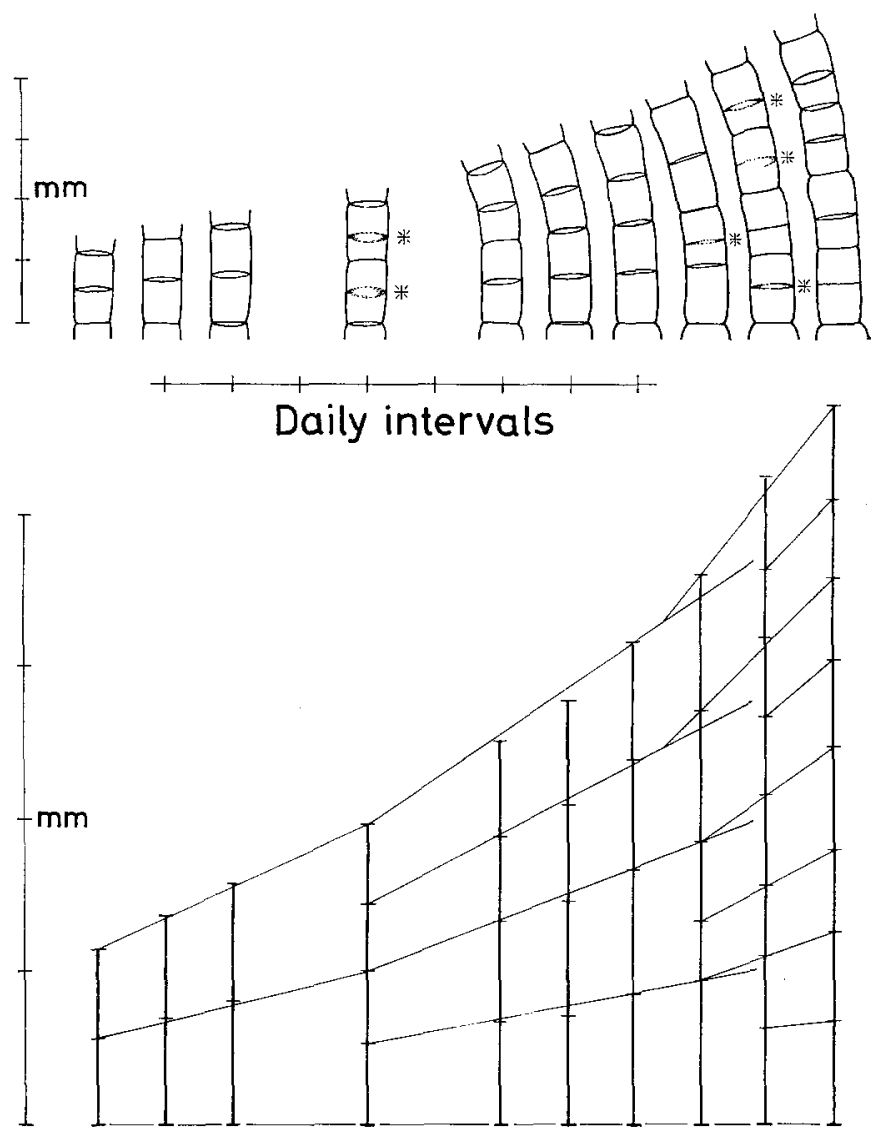

Fig. 15: Chaetomorpha darwinii. Details of growth. (See text for further explanation. Modified after KorNMANN 1969)

Details of growth are presented in Figure 15; dividing cells are marked with an asterisk. Under the conditions of the present experiment, division occurs at an interval of 5 to 6 days. In the diagram beneath, only cell lengths are given and corresponding points are connected by lines. The resulting lines are straight throughout the existence of every individual cell, indicating that there is no change in growth rate. Hence, the exponential growth of the filament represents the sum of uniformly growing cells which duplicate periodically.

Uniformity of growth rates, however, is a simplification resulting from the 
method of registration, which was confined to taking only one photo per day. The growth rates are, in fact, distinctly influenced by the daily rhythm of illumination. Two observations may suffice to verify this statement (Fig. 16). The cells increase more rapidly during the light period than during the dark period. The uniform

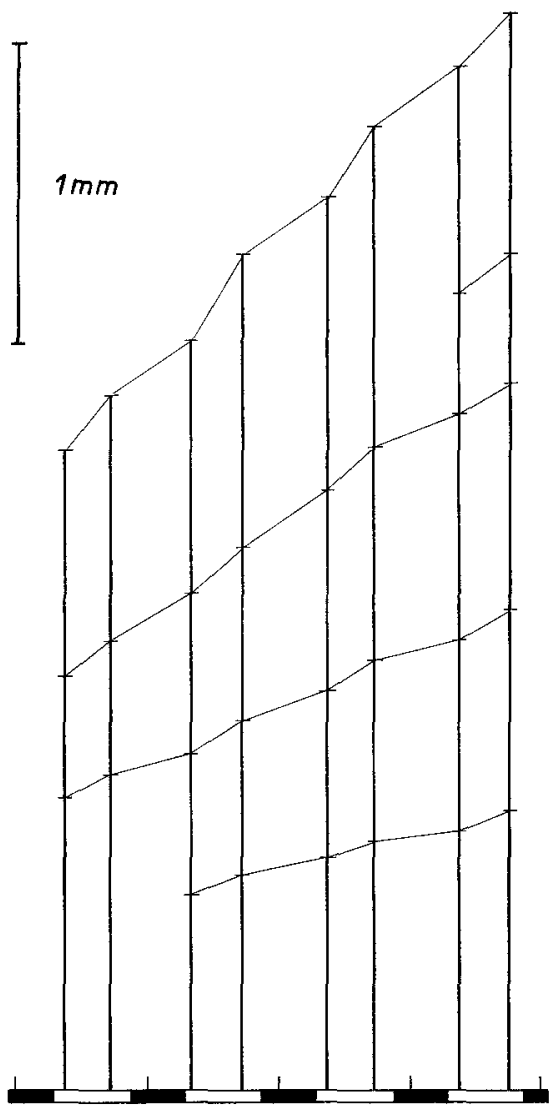

Fig. 16: Chaetomorpha darwinii. Periodicity of growth in light-dark rhythm of $14: 10$ hours. (After KORNMANN 1969)

behaviour of all cells of the filament tip is remarkable. A reaction like this demonstrates the suitability of Chaetomorpha darwinii for studies both in developmental and cellular physiology, especially on account of its large cells. As the protoplasmatic layer is rather transparent, cell division can be easily studied. Centripetal sectioning of an apical and an intercalary cell are shown in Figure 17. Like an iris diaphragm, the margin of the cross-wall advances steadily towards the centre. The rate of this movement is constant with an average speed of $17 \mu / \mathrm{h}$. Cells of $0.5 \mathrm{~mm}$ in diameter divide within some $14 \mathrm{~h}$, those of $1.5 \mathrm{~mm}$ need more than 2 days. This fact causes another regularity: the cross-wall area produced within equal periods of the process 


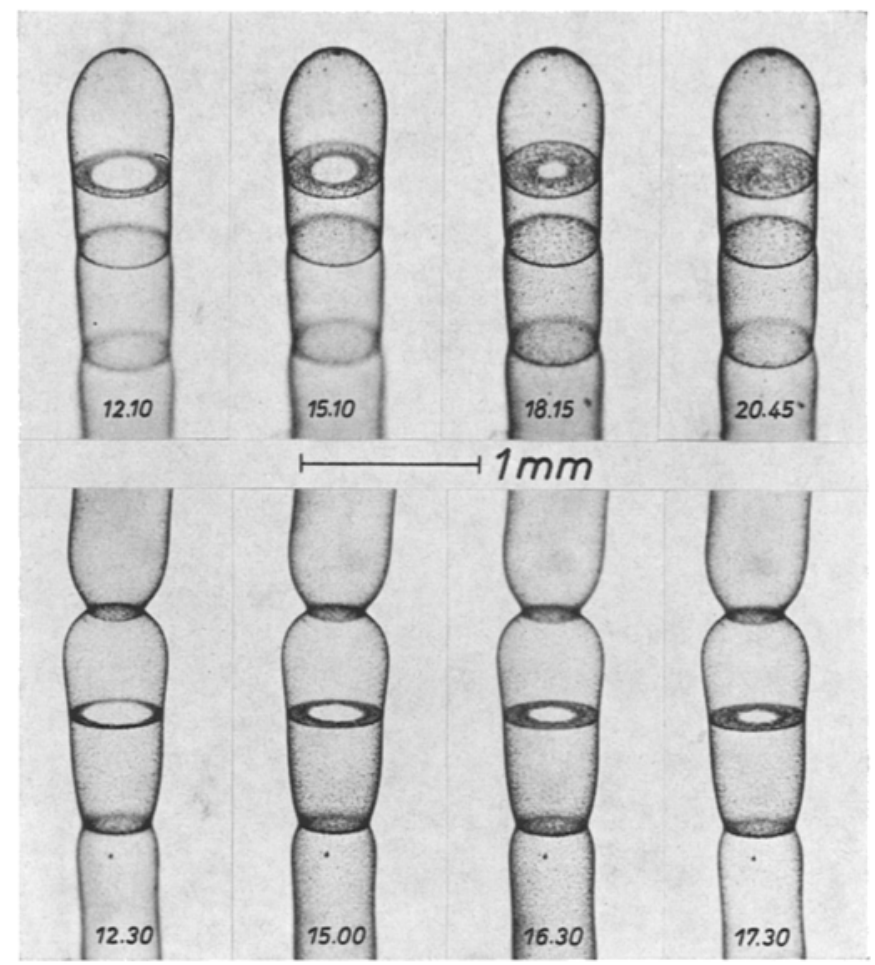

Fig. 17: Chaetomorpha darwinii. Centripetal sectioning of an apical and an intercalary cell. (After KorNMANn 1969)

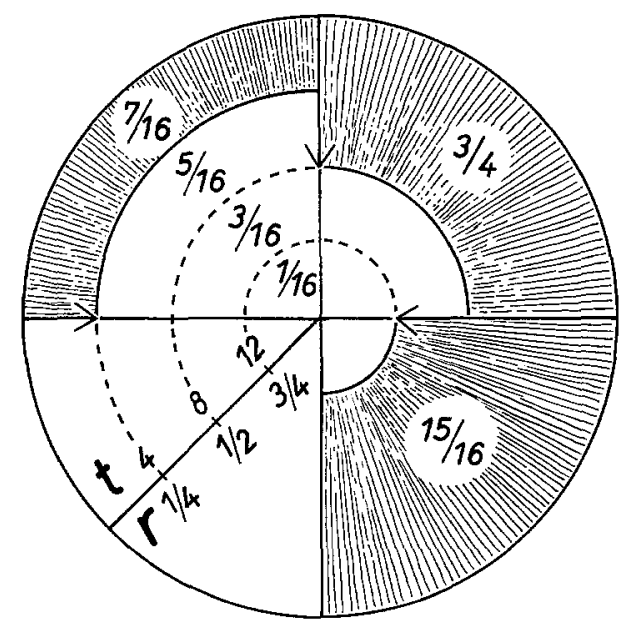

Fig. 18: Chaetomorpha darwinii. Diagram of cross-wall increase, see text for further explanation. (After Kornmann 1969) 
diminishes steadily, as will be shown in a diagram (Fig. 18). Supposing the whole process takes $16 \mathrm{~h}, 7 / 16$ of the new cross-wall are produced within $4 \mathrm{~h}, 12 / 16$ within $8 \mathrm{~h}$, whereas only $1 / 16$ of the cross-wall is built in the last $4 \mathrm{~h}$ (Konnmann 1969).

\section{CULTIVATION AS A MEANS FOR TAXONOMICAL RESEARCH}

Numerous species of Chaetomorpha have been described, they were distinguished mainly by morphological characteristics such as diameter of filaments or the length and width of their cells. Evidently these characteristics cannot sufficiently define a species, since they are variable. This is the reason for the hopeless confusion in the taxonomy of the genus. There is urgent need for characterization of its species on the basis of biological features, such as life history and ontogenetical development. The necessary information can be obtained in cultivation experiments only. Comparison of field samples with cultures represent a useful technique.

Chaetomorpha species of European coasts are now being investigated. While it is not possible here to give a detailed account of the results so far obtained, it can be pointed out that all species hitherto studied feature sufficiently objective biological characteristics for proper taxonomic distinction.

The genus Acrosiphonia, too, is in urgent need of additional biological characterization. With regard to its extensive morphological variability a clear distinction of the Acrosiphonia arcta-complex is practically impossible. There exist, however, definite differences in the life histories of individual samples. By courtesy of several collegues, I was able to compare material from European coasts in culture. Besides different responses to equal culture conditions, they differed significantly in their life histories. Three types of life cycles can be distinguished: (1) succession of isomorphic gametophytes; (2) alternation of heteromorphic generations, the sporophyte representing a unicellular Codiolum-stage; (3) succession of merely asexual generations reproducing by neutral biflagellate swarmers.

Each of these 3 groups, apparently, may include more than one species. As for the European taxa in Ulvales, BLIDING $(1963,1968)$ has recently published a critical survey. To cite but one instance, Monostroma (a depository of heterogeneous forms) has been divided into several genera, mainly on the basis of information on ontogenetical developments and life cycles.

\section{PHYLOGENETIC RELATIONSHIPS}

A satisfactory systematical classification requires comprehensive knowledge on individual species, including their morphology and development; physiology and genetics; biochemistry and ultrastructure. Far from having sufficient knowledge at hand, we must try to establish a system based on the facts available, and accept the need for continued changes.

Some years ago I drew attention to the importance of the Codiolum-stage as a significant systematical feature (KorNmanN 1963, 1965b). As we have seen above, 
this unicellular phase is an essential part in the life cycles of species of Urospora, Spongomorpha and Acrosipbonia respectively; it also occurs in the life histories of species of Ulothrix and Monostroma. All these genera correspond with regard to the simplicity of their morphological structure. Ulotbrix and Urospora are constituted of unbranched monosiphonous filaments, whereas these are branched in Acrosipbonia. Monostroma is characterized by a one-layered frond, as its name indicates. This frond develops ontogenetically from a small disc, which changes into a globular sack by local growth of the central portion. Generally, this slender sack is split into a flattened membrane by mechanical influence, otherwise the monostromatic frond appears, after the closed sack has become fertile, in the tip-region. Heteromorphic life cycle and simplicity of structure are co-ordinated and confined to all these genera of green algae. The two other instances of heteromorphic generations which are found in the genera Derbesia and Chaetophora, bear no relation to one another or to the group of algae under consideration.

On account of their heteromorphic life cycle, the genera referred to have already become types of special systematical entities. The Acrosiphoniales have been separated by Jónsson (1962) from the Cladophorales which are similar in appearance. DEN HaRTog (1959) created the family Codiolaceae to include the genus Urospora. As early as 1934 KunIEDA proposed to look at Monostroma as the type of an independent family (SUNEson 1947).

In 1965, I incorporated the Monostromataceae and the Codiolaceae in the order of Ulotrichales, correcting this in an additional note by raising the Codiolaceae to the rank of an order and indicating the eventuality of a common phylogenetical origin of these two orders and also of the Acrosiphoniales. In the meantime, the results of my studies - mainly the similarities in the ontogenetical development of the Codiolum stage - encourage me, to introduce the new class of the Codiolophyceae. This new class is placed near the Chlorophyceae and includes the Ulotrichales, Codiolales and Acrosiphoniales. I admit that this proposal may be regarded as revolutionary, but it corresponds to the disaggregation of the classification system according to additional new knowledge on basic phycological features.

\section{ADDITIONAL EXAMPLES OF THE IMPORTANCE OF ALGAL CULTURES}

So far, we have dealt with representatives of green, brown or red algae. Successful work has also been carried out on other groups such as diatoms and peridineans. Unialgal cultures are sufficient for such investigations; they contain no "contaminations" other than bacteria. Seawater enriched with nutrients is used as culture medium. Obviously, such conditions are quite artificial, they cannot be compared with conditions in the natural environment. It is, indeed, remarkable that an alga may flourish in a small dish within some twenty millilitres of nutrient solution and still remains comparable in regard to functions and structures to specimens obtained in the field.

Nutritional studies, of course, require the use of axenic algae strains and chemically defined culture media. Further, it may be briefly mentioned that the morphogenetical and cytochemical work of HämmerdING $(1944,1963)$ and his co-workers 
has been done on Acetabularia cultures in the laboratory. Investigations on algal pigments, photosynthesis and ultrastructure are generally based on the use of defined strains from culture collections. Finally, algae are needed as food sources in rearing experiments on marine animals for scientific and practical purposes, a topic which received attention in many papers presented at this International Symposium.

\section{SUMMARY}

1. Cultivation of marine algae under laboratory conditions represents an indispensable prerequisite in many fields of modern phycology. Primarily used for the elucidation of complete life histories, cultivation has proved useful for studies on growth and cell-division.

2. Algal genera of simple morphological structure often lack definite characteristics for species distinction. Culture experiments provide us with additional information which may serve as a basis for modern taxonomical research.

3. Additional knowledge obtained in culture research is likely to result in a better understanding of phylogenetic relationships.

4. The paper provides pertinent examples for each of the statements made under points 1 to 3 which are, to a great extent, based on the author's own work.

\section{LITERATURE CITED}

BuIding, C., 1963. A critical survey of European taxa in Ulvales. I. Capsosiphon, Percursaria, Blidingia, Enteromorpha. Opera Bot. 8 (3), 1-160.

- 1968. A critical survey of European taxa in Ulvales. II. Ulva, Ulvaria, Monostroma, Kornmannia. Bot. Notiser 121, 535-629.

Drew, K. M., 1949. Conchocelis-phase in the life-history of Porpbyra umbilicalis (L.) Kütz. Nature, Lond. 164, 748-749.

- 1954. Studies in the Bangioideae. III. The life-history of Porpbyra umbilicalis (L.) Kütz. var. laciniata (Light.) J. Ag. Ann. Bot. (N.S.) 18, 183-211.

Feldmann, J., 1950. Sur l'existence d'une alternance de générations entre l'Halicystis parvula Schmitz et le Derbesia tenuissima (De Not.) Crn. C. r. hebd. Séanc. Acad. Sci., Paris 230, 322-323.

- 1952. Les cycles de reproduction des algues et leurs rapports avec la phylogénie. Revne Cytol. Biol. vég. 13,1-49.

Förn, B., 1929. Untersuchungen über die Sexualität und Entwicklung von Algen. IV. Vorläufige Mitteilung über die Sexualität und den Generationswechsel von Cladopbora und Ulva. Ber. dt. bot. Ges. 47, 495-506.

- 1934a. Lebenszyklus, Cytologie und Sexualität der Chlorophycee Cladophora Subriana Kützing. Arch. Protistenk. 83, 1-56.

- 1934b. Lebenszyklus und Sexualität der Chlorophycee Ulva lactuca L. Arch. Protistenk. 83, 154-177.

HÄmmerling, J., 1944. Zur Lebensweise, Fortpflanzung und Entwicklung verschiedener Dasycladaceen. Arch. Protistenk. 97, 7-56.

- 1963. Nucleo-cytoplasmic interactions in Acetabularia and other cells. Ann. Rev. Plant Physiol. 14, 65-92. 
Hartmann, M., 1929. Untersuchungen über die Sexualität von Algen. III. Über die Sexualität und den Generationswechsel von Chaetomorpha und Enteromorpha. Ber. dt. bot. Ges. 47, $485-494$.

Hartog, C. DEN, 1959. The epilithic algal communities occurring along the coasts of the Netherlands. Wentia 1, 1-241.

Hollenberg, G. J., 1935. A study of Halicystis ovalis. I. Morphology and reproduction. Am. J. Bot. 22, 782-812.

Hustede, H., 1964. Entwicklungsphysiologische Untersuchungen über den Generationswechsel zwischen Derbesia neglecta BERTH. und Bryopsis balymeniae BERTH. Botanica mar. 6, $134-142$.

Jónsson, S., 1962. Redherches sur les Cladophoracées marines (structure, reproduction, cycles comparés, conséquences systématiques). Annls Sci. nat. (Bot.) Sér. 12, 3, 25-230.

Kornmann, P., 1938. Zur Entwicklungsgeschichte von Derbesia und Halicystis. Planta 28, 464-470.

- 1961a. Über Codiolum und Urospora. Helgoländer wiss. Meeresunters. 8, 42-57.

- 1961b. Die Entwicklung von Porphyra leucosticta im Kulturversuch. Helgoländer wiss. Meeresunters. 8, 167-175.

- 1963. Die Ulotrichales, neu geordnet auf der Grundlage entwicklungsgeschichtlicher Befunde. Pbycologia 3, 60-68.

- 1964. Zur Biologie von Spongomorpha aeruginosa (LinNaEus) van DEN HoEk. Helgoländer wiss. Meeresunters. 11, 200-208.

- 1965a. Zur Analyse des Wachstums und des Aufbaus von Acrosiphonia. Helgoländer wiss. Meeresunters. 12, 219-238.

- 1965b. Ontogenie und Lebenszyklus der Ulotrichales in phylogenetischer Sicht. Phycologia $4,163-172$.

- 1966a. Wachstum und Zellteilung bei Urospora. Helgoländer wiss. Meeresunters. 13, 73-83.

- 1966b. Eine erbliche Variante von Derbesia marina. Naturwissenschaften 53, 161.

- 1968. Benthosalgen. In: Methoden der meeresbiologischen Forschung. Hrsg. von C. Schlieper. VEB G. Fischer, Jena, 171-182.

- 1969. Gesetzmäßigkeiten des Wachstums und der Entwicklung von Chaetomorpha darwinii (Chlorophyta, Cladophorales). Helgoländer wiss. Meeresunters. 19, 335-354.

Neumann, K., 1969. Beitrag zur Cytologie und Entwicklung der siphonalen Grünalge Derbesia marina. Helgoländer wiss. Meeresunters. 19, 355-375.

Sauvageau, C., 1915. Sur la sexualité hétérogamique d'une Laminaire (Saccorbiza bulbosa). C. r. hebd. Séanc. Acad. Sci., Paris 161, 796-799.

SCHREIBER, E., 1930. Untersuchungen über Parthenogenesis, Geschlechtsbestimmung und Bastardierungsvermögen bei Laminarien. Planta 12, 331-353.

Suneson, S., 1947. Notes on the life-history of Monostroma. Svensk bot. Tidskr. 41, 235-246.

Suto, S., 1966. Culture of Porphyra in laboratory. In: Cultures and collections of algae. Proceedings of U.S.-Japan Conference, Hakone, Sept. 1966. Ed. by A. Watanabe \& A. Hattori. Jap. Soc. Plant Physiol., 59-62.

Author's address: Dr. P. KornmanN

Biologische Anstalt Helgoland

Meeresstation

2192 Helgoland

Germany (FRG) 